\title{
Nutritional quality and bioactive compounds of partially defatted baru almond flour
}

\author{
Ana Paula Silva SIQUEIRA ${ }^{1}$, Maria Teresa Bertoldo PACHECO $^{2}$, Maria Margareth Veloso NAVES ${ }^{3 *}$
}

\begin{abstract}
This study aimed to investigate the nutritional quality and bioactive potential of partially defatted baru (Dipteryx alataVog.) almond flour (BAF). The flour's proximate and mineral compositions, total phenolic, tocopherols and carotenoids contents, antioxidant capacity, trypsin inhibitor and amino acid analyses were performed. An experiment was conducted with 24 male Wistar rats in order to evaluate the flour's protein quality. BAF has high protein, fiber and mineral contents (iron, zinc, magnesium and copper), and it is a source of calcium. BAF presented relevant amounts of total phenolics $(625 \mathrm{mg} / 100 \mathrm{~g})$ and good antioxidant capacity $(130 \mu \mathrm{mol} /$ Trolox eq). Autoclaved BAF showed essential amino acids profile, digestibility and protein quality better than in natura BAF. Autoclaved BAF might be used for human consumption as a source of quality protein and bioactive compounds, in healthy diets and processed foods.
\end{abstract}

Keywords: baru seed; protein; chemical composition; amino acids; antioxidants.

Practical Application: Defatted baru almond flour is a bioactive compound-rich raw material for healthy and innovative foods.

\section{Introduction}

Nuts and edible seeds contain high amounts of lipids, proteins, dietary fiber and ashes (minerals), and present a favorable essential amino acids profile, usually with slight lysine deficiency. These foods constitute protein and bioactive compounds sources for vegetable-based diets, since the consumption of nuts and edible seeds is associated with lower chronic diseases risk (Freitas \& Naves, 2010).

Baru almond (Dipteryx alata Vog.) is an edible seed, native from the Brazilian Savannah. This exotic seed is rich in proteins (approximately $30 \mathrm{~g} / 100 \mathrm{~g}$ ), lipids (around $40 \mathrm{~g} / 100 \mathrm{~g}$ ) and fibers $(12 \mathrm{~g} / 100 \mathrm{~g})$. Moreover, baru almond is a mineral source, chiefly of calcium, iron and zinc (Czeder et al., 2012; Sousa et al., 2011). Besides its nutritional properties, the baru almond has become an important native fruit from Brazil because of its health benefits, as reported in a clinical trial (Bento et al., 2014), although studies on its bioactive potential are scarce.

The oil constitutes one of the baru almond's co-products, with social and commercial importance, including exportation. Baru oil extraction is handmade, performed in cooperatives by mechanical pressing, and generates the partially defatted baru almond flour (BAF), which is commercialized for animal feed. BAF presents nutritional relevance, mainly due to its high protein contents $(49 \mathrm{~g} / 100 \mathrm{~g})$ and ashes $(5 \mathrm{~g} / 100 \mathrm{~g})$ (Guimarães et al., 2012). However, there are no studies on bioactive potential and protein quality of this flour.

Considering the nutritive potential of baru almond, and the tendency of using nutritive co-products of the agroindustry for human consumption, the objective of this study was to investigate the nutritional and biological quality of partially defatted BAF.

\section{Materials and methods}

\subsection{Sample collection}

The fruits were collected from a region of the Brazilian Savannah, located at southeast of Goiás State (coordinates: $17^{\circ} 27^{\prime} 51.83^{\prime \prime} \mathrm{S}$ and $48^{\circ} 12^{\prime} 12.51^{\prime \prime} \mathrm{W}$, and altitude of $779 \mathrm{~m}$ ), during harvest season, between August and September, from eight trees, at least $200 \mathrm{~m}$ distant. The collected fruits (total $=1200$ ) were those recently fallen on the ground, in perfect morphological condition. The baru almonds were extracted using a guillotine and were stored at temperature between $5{ }^{\circ} \mathrm{C}$ and $10{ }^{\circ} \mathrm{C}$ until analysis, which were carried out in whole baru almond (in natura), in natura BAF and autoclaved BAF.

\subsection{Partially defatted BAF processing}

The oil of baru almonds (in natura and with peel) were extracted by hydraulic machine (Carver, model C, serie \#24000-415, USA) without heating and with controlled pressure (9 ton). The co-product obtained was powdered (Skymsen, PA- 7SE processor, $60 \mathrm{~Hz}$ and $0.33 \mathrm{CV} / 245 \mathrm{w}$, Brazil) and sieved (Retsch, $10 \mathrm{mesh}$, Germany). The partially defatted BAF generated (Figure 1) was divided in two lots: in natura BAF and autoclaved BAF $\left(131{ }^{\circ} \mathrm{C}\right.$ for $30 \mathrm{~min}$ ). 

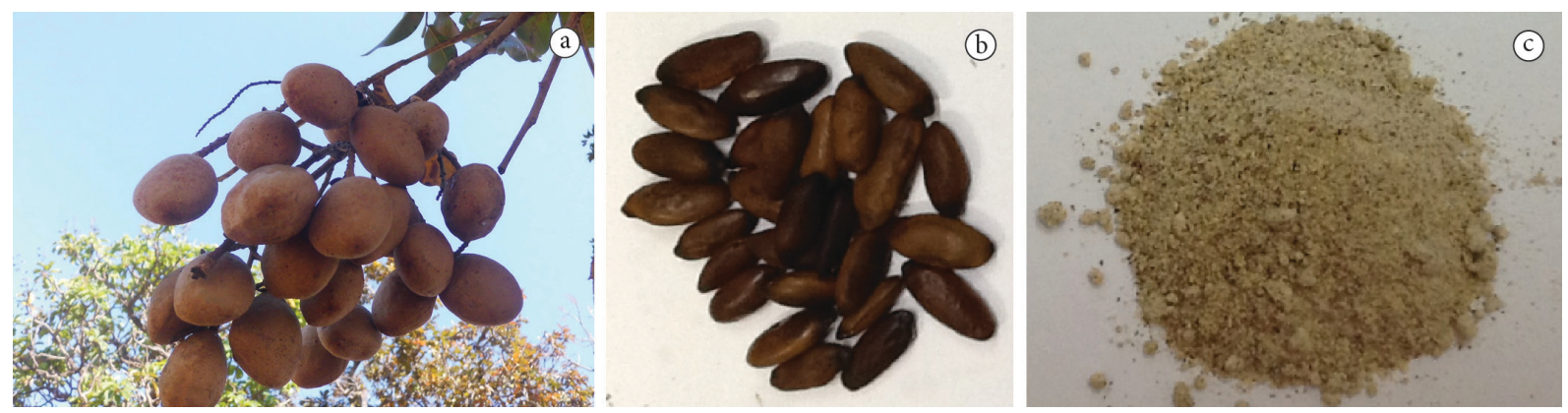

Figure 1. Baru: (a) fruit; (b) almond and (c) partially defatted almond flour (BAF).

\subsection{Macronutrients and minerals determination}

The following chemical composition parameters were determined in triplicate: moisture (Association of Official Analytical Chemists, 2010); nitrogen content by the micro-kjeldahl method (Association of Official Analytical Chemists, 2010) using a conversion factor 6.25; total lipids, by soxhlet (Association of Official Analytical Chemists, 2010); ashes at $550{ }^{\circ} \mathrm{C}$ (Association of Official Analytical Chemists, 2010) and total dietary fiber, according to the enzymatic-gravimetric technique (Prosky et al., 1988). The carbohydrate content was estimated: 100 - (moisture + protein + lipid + dietary fiber + ash). The energy was estimated using Atwater conversion factors of $4 \mathrm{kcal}$ (protein and carbohydrate) and $9 \mathrm{kcal}$ (lipid) (Merril \& Watt, 1973).

The minerals were quantified, in triplicate, after digestion of organic matter with nitric acid and nitrogen peroxide (Slavin et al., 1975), by ICP-OES (Inductively Coupled Plasma-Optical Emission Spectrometry).

\subsection{Bioactive compounds and antioxidant capacity analyses}

In order to determine total phenolics, Folin-Ciocalteu (Genovese et al., 2008) method was adopted. Gallic acid was used as spectrophotometric standard (Varian, model Cary 50 Scan, USA) and total phenolic content was expressed as gallic acid equivalent (GAE/100g of fresh sample). Tocopherols were analyzed by High Performance Liquid Chromatography (HPLC) system (Shimadzu, model Luna/Phenomenex $4.6 \times 250 \mathrm{~mm}$, Japan); the peaks were identified through comparison with the retention times of authentic standards by DAD (Diode Array Detector) and the quantification was done by external calibration (American Oil Chemist's Society, 2009). Total carotenoids were determined as described by Higby (1962) and the reading was done by HPLC (Shimadzu, model Luna/Phenomenex $4.6 \times 250 \mathrm{~mm}$, Japan) (Ramos et al., 2001).

Antioxidant capacity was determined through 2.2-diphenyl-1-picrylhydrazyl (DPPH) free radical scavenging (Blois, 1958; Brand-Williams et al., 1995), using stable DPPH, which suffers reduction by antioxidants with color change from violet to yellow. The absorbance was read in a UV spectrophotometer (Varian, model Cary 50 Scan, USA) at $515 \mathrm{~nm}$.

\subsection{Trypsin inhibitor analysis}

Trypsin inhibitor was determined in BAF extracts prepared with $\mathrm{NaOH}$, and placed in the presence of trypsin, BAPA (Benzoyl-L-arginine-p-nitroanilide) and TCA (trichloroacetic acid). After centrifugation, the supernatant was collected and the absorbance was read in a spectrophotometer (Varian, model Cary 50 Scan, USA) at $410 \mathrm{~nm}$ (American Oil Chemist's Society, 2009).

\subsection{Amino acids analysis}

The amino acid analysis was performed, in triplicate, by acid hydrolysis of proteins and peptides (Moore \& Stein, 1951). The hydrolyzed samples were placed in an automatic amino acids analyzer (Nicolas V, University of São Paulo Protein Chemistry Center, Ribeirão Preto-SP). After elution in the column and reaction with ninhydrin, the amino acids were quantified by a colorimetric assay. The results of this analysis were used to estimate the amino acid score (AAS) by using the following formula (World Health Organization, 2007): (mg of amino acid in $1 \mathrm{~g}$ of test protein $/ \mathrm{mg}$ of amino acid in requirement pattern) x 100 .

\subsection{Biological assay}

In order to evaluate the protein quality of BAF, a biological assay was carried out, after its approval by the Animal Use Ethics Committee of the Federal University of Goiás (Protocol $\left.\mathrm{n}^{\circ} 153 / 2008\right)$. Twenty-four weanling male Wistar rats were distributed in four groups of six. Animals' body weight and food consumption were assessed throughout the experiment. Four diets were prepared, according to AIN-93G (Reeves et al., 1993), as following: reference (with casein); protein-free diet and two experimental diets -in natura and autoclaved BAF (Table 1). Diets were analyzed regarding protein and lipid contents, in order to confirm its isoproteic and isolipidic formulations (Table 1).

In natura and autoclaved BAF protein values were estimated through Net Protein Ratio (NPR) and Protein Digestibility-Corrected Amino Acid Score (PDCAAS) indexes. NPR and Relative NPR (RNPR) were calculated, as follows (Pellet and Young, 1980): $\mathrm{NPR}=$ [test-group weight gain $(\mathrm{g})$ - protein-free group weight loss $(\mathrm{g})] /$ consumed protein by test group; and RNPR $=[$ (test group NPR)/reference group NPR) $\times 100]$. True digestibility (\%) was determined according to the Food and Agriculture Organization of the United Nations (1991), for in vivo tests. The 
Table 1. Composition of experimental diets.

\begin{tabular}{|c|c|c|c|c|}
\hline \multirow{2}{*}{$\begin{array}{l}\text { Content } \\
(\mathrm{g} / 100 \mathrm{~g})\end{array}$} & \multicolumn{4}{|c|}{ Diet } \\
\hline & $\begin{array}{c}\text { Casein } \\
\text { (reference) }\end{array}$ & $\begin{array}{c}\text { In natura } \\
\text { BAF }\end{array}$ & $\begin{array}{c}\text { Autoclaved } \\
\text { BAF }\end{array}$ & $\begin{array}{l}\text { Protein- } \\
\text { free }\end{array}$ \\
\hline \multicolumn{5}{|l|}{ Ingredient } \\
\hline Casein & 12.50 & - & - & - \\
\hline BAF & - & 36.20 & 35.08 & - \\
\hline Soybean oil & 6.70 & 2.33 & 2.30 & 7.00 \\
\hline Mineral mix & 3.50 & 3.50 & 3.50 & 3.50 \\
\hline Vitamin mix & 1.00 & 1.00 & 1.00 & 1.00 \\
\hline $\begin{array}{l}\text { Choline } \\
\text { bitartrate }\end{array}$ & 0.25 & 0.25 & 0.25 & 0.25 \\
\hline Corn starch & 70.87 & 56.72 & 57.87 & 83.25 \\
\hline L-cystine & 0.18 & - & - & - \\
\hline Fiber (cellulose) & 5.00 & - & - & 5.00 \\
\hline \multicolumn{5}{|l|}{$\begin{array}{l}\text { Chemical } \\
\text { composition }\end{array}$} \\
\hline Protein & $10.72 \pm 0.26^{\mathrm{a}}$ & $10.39 \pm 1.24^{\mathrm{a}}$ & $11.65 \pm 0.06^{\mathrm{a}}$ & $0.24 \pm 0.03^{\mathrm{b}}$ \\
\hline Lipids & $7.53 \pm 0.58^{\mathrm{a}}$ & $7.16 \pm 0.51^{\mathrm{a}}$ & $7.68 \pm 0.32^{\mathrm{a}}$ & $7.49 \pm 0.52^{\mathrm{a}}$ \\
\hline
\end{tabular}

rats' feces were collected and marked during the experiment's second week for nitrogen analysis. PDCAAS was estimated as follows: PDCAAS $=$ [test protein AAS $(\%) \times$ test protein True Digestibility (\%)]/100 (Food and Agriculture Organization of the United Nations, 1991; World Health Organization, 2007).

\subsection{Statistical analysis}

Results were submitted to variance analysis (ANOVA) followed by Tukey test, at $5 \%$ probability, except for comparison between two data groups, in which Student t-test was employed. It was performed a linear regression analysis between the animal's body weight and the days of experiment.

\section{Results}

The whole baru almond's moisture was approximately $7 \mathrm{~g} / 100 \mathrm{~g}$, which was preserved in the autoclaved BAF. In natura and autoclaved BAF presented high protein, dietary fiber and ash contents, in addition to a residual lipid content of $13 \%$. As a result of lipid extraction, BAF's energy was lower and the macronutrients contents were higher than those of whole baru almond (Table 2).

BAF is rich in iron, magnesium and zinc, and it is also calcium source. The flour presented higher contents of these minerals than those of whole baru almond (Table 3).

Regarding bioactive compounds (Table 4), BAF showed higher phenolic contents and antioxidant capacity than that of whole baru almond. Tannin and phytate contents were reduced by the flour's autoclaving process, since autoclaved BAF showed lower contents of these compounds than those of in natura BAF. Alpha- and gamma-tocopherol were the main isomers of the tocopherol found in baru almonds. BAF contain low amounts of tocopherols and carotenoids.
Table 2. Proximate composition and energy of whole baru almond and in natura and autoclaved baru almond flour (BAF).

\begin{tabular}{lrrr}
\hline \multicolumn{1}{c}{ Content } & $\begin{array}{c}\text { Whole baru } \\
\text { almond }\end{array}$ & $\begin{array}{c}\text { In natura } \\
\text { BAF }\end{array}$ & \multicolumn{1}{c}{$\begin{array}{c}\text { Autoclaved } \\
\text { BAF }\end{array}$} \\
\hline $\begin{array}{l}\text { Proximate composition } \\
\text { (g/100g) }\end{array}$ & & & \\
Moisture & $7.38 \pm 0.19^{\mathrm{b}}$ & $9.95 \pm 0.21^{\mathrm{a}}$ & $7.16 \pm 0.00^{\mathrm{b}}$ \\
Protein & $19.72 \pm 0.11^{\mathrm{c}}$ & $27.83 \pm 0.58^{\mathrm{b}}$ & $29.05 \pm 0.15^{\mathrm{a}}$ \\
Lipids & $38.37 \pm 0.07^{\mathrm{a}}$ & $12.59 \pm 0.28^{\mathrm{b}}$ & $12.97 \pm 0.13^{\mathrm{b}}$ \\
Ashes & $2.46 \pm 0.43^{\mathrm{b}}$ & $3.81 \pm 0.16^{\mathrm{a}}$ & $3.82 \pm 0.05^{\mathrm{a}}$ \\
Dietary fiber & $12.60 \pm 0.30^{\mathrm{b}}$ & $16.12 \pm 0.39^{\mathrm{a}}$ & $17.36 \pm 0.07^{\mathrm{a}}$ \\
Carbohydrates & $19.47 \pm 0.22^{\mathrm{b}}$ & $30.15 \pm 0.32^{\mathrm{a}}$ & $29.64 \pm 0.08^{\mathrm{a}}$ \\
Energy $(k c a l / 100 g)$ & $502.09 \pm 0.22^{\mathrm{a}}$ & $345.23 \pm 0.32^{\mathrm{b}}$ & $351.49 \pm 0.08^{\mathrm{b}}$ \\
\hline Values are mean \pm standard deviation of three replicates; nitrogen conversion factor to \\
raw protein: 6.25; (a,b) means with the same letter in the same row are not significantly \\
different (Tukey test, $p<0.05)$.
\end{tabular}

Table 3. Mineral composition of whole baru almond and in natura baru almond flour (BAF) and relation to Estimated Average Requirements (EAR).

\begin{tabular}{lrrcc}
\hline $\begin{array}{c}\text { Mineral } \\
(\mathrm{mg} / 100 \mathrm{~g})\end{array}$ & $\begin{array}{c}\text { Whole baru } \\
\text { almond }\end{array}$ & $\begin{array}{c}\text { In natura } \\
\text { BAF }\end{array}$ & $\begin{array}{c}\text { EAR } \\
(\mathrm{mg} / \text { day })\end{array}$ & $\begin{array}{c}\text { \% EAR of in } \\
\text { natura BAF }\end{array}$ \\
\hline Calcium & $88 \pm 3.00^{\mathrm{b}}$ & $122 \pm 7.00^{\mathrm{a}}$ & 800 & 15 \\
Cooper & $1 \pm 0.04^{\mathrm{a}}$ & $1 \pm 0.04^{\mathrm{a}}$ & 0.7 & 143 \\
Iron & $3 \pm 0.20^{\mathrm{b}}$ & $5 \pm 0.30^{\mathrm{a}}$ & 6 & 83 \\
Magnesium & $107 \pm 3.00^{\mathrm{b}}$ & $136 \pm 6.00^{\mathrm{a}}$ & 350 & 39 \\
Selenium & $0.1 \pm 0.01$ & - & 45 & - \\
$(\mu \mathrm{g} / 100 \mathrm{~g})$ & $2 \pm 0.02^{\mathrm{a}}$ & $0.3 \pm 0.04^{\mathrm{b}}$ & 1500 & 0.02 \\
Sodium & $2 \pm 0.10^{\mathrm{b}}$ & $4 \pm 0.20^{\mathrm{a}}$ & 9.4 & 43 \\
Zinc & & & & \\
\hline
\end{tabular}

Values are mean \pm standard deviation of three replicates; EAR for men with 31-50 years old (Institute of Medicine, 2014); $\left.{ }^{(\mathrm{a}, \mathrm{b}}\right)$ means with the same letter in the same row are not significantly different (Student $\mathrm{t}$ - test, $p<0.05$ ); sodium value corresponding to Adequate Intakes (AIs).

Table 4. Bioactive compounds of whole baru almond and in natura and autoclaved baru almond flours (BAF).

\begin{tabular}{lccc}
\hline \multicolumn{1}{c}{ Content } & $\begin{array}{c}\text { Whole baru } \\
\text { almond }\end{array}$ & In natura BAF & $\begin{array}{c}\text { Autoclaved } \\
\text { BAF }\end{array}$ \\
\hline $\begin{array}{l}\text { Bioactive compounds } \\
\left(\begin{array}{l}\text { mg/100g }) \\
\text { Phenolics }\end{array}\right.\end{array}$ & $388.04 \pm 47.61^{\mathrm{c}}$ & $588.11 \pm 63.45^{\mathrm{b}}$ & $662.04 \pm 34.43^{\mathrm{a}}$ \\
Tanins & $562.87 \pm 3.57^{\mathrm{c}}$ & $992.51 \pm 3.95^{\mathrm{a}}$ & $648.26 \pm 3.15^{\mathrm{b}}$ \\
Phytates & $312.68 \pm 0.12^{\mathrm{b}}$ & $447.87 \pm 0.11^{\mathrm{a}}$ & $254.43 \pm 0.15^{\mathrm{c}}$ \\
Tocopherol & $11.61 \pm 0.08^{\mathrm{a}}$ & $1.46 \pm 0.08^{\mathrm{b}}$ & $1.50 \pm 0.08^{\mathrm{b}}$ \\
Carotenoid $(\mu \mathrm{g} / 100 \mathrm{~g})$ & $11.40 \pm 0.40^{\mathrm{a}}$ & $1.43 \pm 0.40^{\mathrm{b}}$ & $1.47 \pm 0.40^{\mathrm{b}}$ \\
Antioxidant capacity & & & \\
$\begin{array}{l}\text { DPPH } \\
(\mu \mathrm{mol} / \text { Trolox eq })\end{array}$ & $67.00 \pm 6.31^{\mathrm{b}}$ & $130.93 \pm 3.27^{\mathrm{a}}$ & $130.46 \pm 7.18^{\mathrm{a}}$ \\
\hline
\end{tabular}

Values are mean \pm standard deviation of three replicates; Baru almond total tocopherol $(\mathrm{mg} / 100 \mathrm{~g})$ : alpha $=7.00$; beta $=0.35$ and gama $=3.5 ;(\mathrm{a}, \mathrm{b})$ means with the same letter in the same row are not significantly different (Tukey test, $p<0.05)$.

The values of trypsin inhibitor were $12.84 \pm 0.10(\mathrm{UTI} / \mathrm{mg})$ for whole baru almond, $12.89 \pm 0.24$ (UTI/mg) for in natura BAF and $0.46 \pm 0.44(\mathrm{UTI} / \mathrm{mg})$ for autoclaved BAF.

In natura BAF is complete in essential amino acids, according to its AAS value (Table 5). Amino acids profile of autoclaved BAF 
Table 5. Amino acid composition of in natura baru almond flour (BAF) and Amino Acid Score (AAS) according to the WHO/FAO/UNU requirement pattern.

\begin{tabular}{lcc}
\hline \multicolumn{1}{c}{$\begin{array}{c}\text { Amino acid } \\
\text { (mg/g protein) }\end{array}$} & $\begin{array}{c}\text { WHO/FAO/UNU } \\
\text { requirement pattern }\end{array}$ & In natura BAF \\
\hline $\begin{array}{l}\text { Indispensable } \\
\text { (Essential) }\end{array}$ & & \\
His & 16.0 & 29.07 \\
I1e & 31.0 & 41.92 \\
Leu & 61.0 & 85.37 \\
Lys & 48.0 & 59.36 \\
Met + Cys & 24.0 & 27.36 \\
Phe + Tyr & 41.0 & 89.35 \\
Thr & 25.0 & 36.72 \\
Trp & 6.6 & 20.20 \\
Val & 40.0 & 47.74 \\
TOTAL & 292.6 & 416.89 \\
AAS (\%) & 100 & 114 \\
Dispensable (Non- & & \\
essential) & & \\
Asp & - & 116.59 \\
Glu & - & 250.61 \\
Ala & - & 41.00 \\
Arg & - & 100.98 \\
Gly & - & 43.15 \\
Pro & - & 40.70 \\
Ser & - & 48.65 \\
TOTAL & & 641.68 \\
\hline Vat & & \\
\hline
\end{tabular}

Values are mean of two replicates; WHO/FAO/ONU requirement pattern of essential amino acids for schoolchildren (World Health Organization, 2007); Trp of in natura BAF: according to Fernandes et al. (2010); bold value indicates the first limiting amino acid.

can be considered similar to that of in natura BAF. Throughout the 14 days of experiment, body weight gain of the animals was positive and linear, except for the protein-free diet group, which showed body weight loss (Figure 2). Determination coefficient $\left(\mathrm{R}^{2}\right)$ values ranged from 0.69 to 0.97 for the body weight curves. The in natura BAF diet group showed a very low weight gain, and the autoclaved BAF diet group's weight gain was similar to that of the reference group.

True digestibility of in natura BAF was approximately $50 \%$, and the autoclaving process resulted in a $50 \%$ increase of autoclaved BAF protein digestibility. As a result, protein quality of autoclaved BAF, evaluated through PDCAAS and NPR, was higher than that of in natura BAF (Table 6).

\section{Discussion}

The present study's data indicate that BAF is a co-product with high nutritive value and antioxidant capacity. There is no previous research about the in vivo true digestibility and protein quality, total dietary fibers content and bioactive compounds content of the autoclaved BAF.

The autoclaved BAF produced in this study was partially defatted and its lipid content is higher than the value reported by Guimarães et al. (2012) that carried out a preliminary study

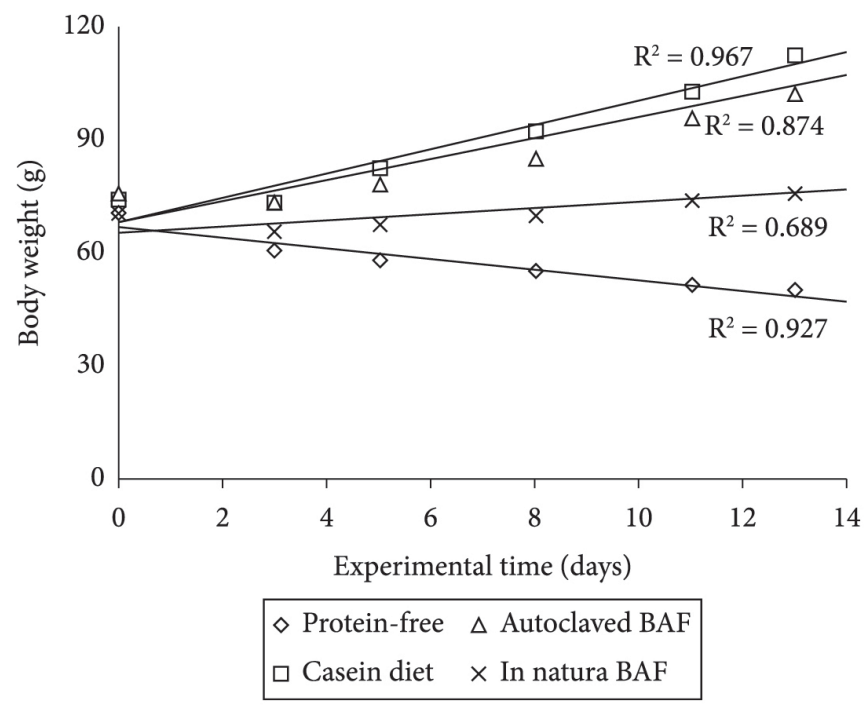

Figure 2. Body weight curves of Wistar male rats treated with different diets (casein, in natura and autoclaved baru almond flour-BAF, and protein-free) during 14 days of experiment.

Table 6. Body weight gain, food and protein intakes, Net Protein Ratio (NPR), Relative NPR (RNPR) and Protein Digestibility-Corrected Amino Acid Score (PDCAAS) of Wistar male rats during 14 days of experiment.

\begin{tabular}{lccc}
\hline \multirow{2}{*}{ Parameter } & \multicolumn{3}{c}{ Diet } \\
\cline { 2 - 4 } & Casein & In natura BAF & Autoclaved BAF \\
\hline $\begin{array}{l}\text { Body weight } \\
\text { gain (g) }\end{array}$ & $44.00 \pm 11.71^{\mathrm{a}}$ & $9.80 \pm 1.72^{\mathrm{b}}$ & $36.73 \pm 3.70^{\mathrm{a}}$ \\
$\begin{array}{l}\text { Total food } \\
\text { intake (g) }\end{array}$ & $150.30 \pm 13.84^{\mathrm{b}}$ & $137.20 \pm 7.82^{\mathrm{c}}$ & $179.10 \pm 21.96^{\mathrm{a}}$ \\
$\begin{array}{l}\text { Total protein } \\
\text { intake (g) }\end{array}$ & $16.11 \pm 1.23^{\mathrm{b}}$ & $14.25 \pm 0.81^{\mathrm{c}}$ & $20.86 \pm 2.55^{\mathrm{a}}$ \\
$\begin{array}{l}\text { True } \\
\text { digestibility (\%) }\end{array}$ & $95.38 \pm 1.91^{\mathrm{a}}$ & $47.95 \pm 3.16^{\mathrm{c}}$ & $71.24 \pm 3.53^{\mathrm{b}}$ \\
NPR & $4.00 \pm 0.48^{\mathrm{a}}$ & $2.27 \pm 0.17^{\mathrm{c}}$ & $2.87 \pm 0.41^{\mathrm{b}}$ \\
RNPR (\%) & 100 & $54.96 \pm 0.17^{\mathrm{b}}$ & $69.52 \pm 0.41^{\mathrm{a}}$ \\
PDCAAS (\%) & - & $55.00 \pm 0.17^{\mathrm{b}}$ & $81.00 \pm 0.41^{\mathrm{a}}$ \\
\hline
\end{tabular}

BAF-Baru Almond Flour; $\left(^{\mathrm{a}, \mathrm{b}}\right)$ means ( \pm standard deviation of six animals) with the same letter in the same row are not significantly different (Tukey test, $p<0.05$ ).

on proximate composition and protein properties of BAF. The autoclaved BAF's residual oil aggregates nutritional value to BAF, since baru oil is rich in unsaturated fatty acids, especially monounsaturated acids (Bento et al., 2014), and contains tocopherols and carotenoids (Table 4).

The autoclaved BAF is rich in total dietary fiber (Table 2), mainly insoluble fibers according to the literature (Czeder et al., 2012). This fact reinforces the potential use of BAF due to the physiological effects of insoluble dietary fibers, such as the increase of fecal volume and the reduction of intestinal transit time (Roberfroid et al., 2010).

BAF's mineral composition is relevant, since zinc is especially important for normal nervous system activity (Stelmashook et al., 2014). The low sodium content of baru almond and BAF (Table 3 ) 
is favorable to health because the high consumption of sodium is an important dietary factor that increases chronic diseases risk (Freitas \& Naves, 2010). Other oilseeds, such as almond, peanut and Brazil nut are mineral sources, mainly calcium, iron and zinc (Freitas \& Naves, 2010).

Concerning bioactive compounds, autoclaved BAF showed higher phenolic contents than in natura BAF, which could be partially explained by the reduction of the autoclaved flour's moisture (Table 2). Both BAF have higher contents of phenolic compounds than those reported in the literature for cashew nut $(106 \mathrm{mg} / 100 \mathrm{~g})$ and Brazil nut $(381 \mathrm{mg} / 100 \mathrm{~g})$. The high phenolic content in nuts is related to high antioxidant capacity (Abe et al., 2010), as observed in the present study for BAF compared to whole baru almond (Table 4).

Tannin and phytate values were reduced in autoclaved BAF compared to in natura BAF (Table 4). It is valid to add that the inactivation of these compounds increases the availability of some minerals for absorption (Weaver \& Kannan, 2002), such as iron and zinc, which are present in high amounts in BAF. Phytates and tannins can bind to minerals, which generates insoluble complexes and unavailable biologically for humans under normal physiological conditions (Raes et al., 2014). In a previous study with baru almond (Togashi \& Sgarbieri, 1994), the authors did not find significant amounts of phytate and tannin in the raw baru almond. These compounds were inactivated after heating treatment, as observed in the present study for BAF.

Regarding the baru almond's alpha-tocopherol content, it is higher than that observed by Takemoto et al. (2001). According to the Institute of Medicine (Institute of Medicine, 2000 ), the daily recommended intake (DRI) for vitamin $\mathrm{E}$ is $15 \mathrm{mg}$ per day, thus the consumption of one portion $(20 \mathrm{~g})$ of baru almond (Bento et al., 2014; Fernandes et al., 2010) provides considerable amounts of vitamin E per day (15\%). It should be stressed that vitamin $\mathrm{E}$ is an important in vivo antioxidant (Niki, 2014), so it may contribute to the high BAF antioxidant capacity. Additional in vivo studies are required to highlight the biological antioxidant activity of the autoclaved BAF, since the DPPH is an in vitro method used for initial evaluation of the antioxidant properties (Alves et al., 2010).

In the present study, the analysis of the amino acid profile was performed only in the in natura BAF sample (Table 5), since the amino acid contents do not change significantly with heating (roasting or autoclaving) (Freitas et al., 2012). On the other hand, studies showed that the amino acids profile of the baru almond may be influenced by the native area of the fruit (Czeder et al., 2012; Fernandes et al., 2010).

BAF has high good quality protein contents. Studies with baru almonds from different region of the Brazilian Savannah reported AAS values from $75 \%$ (Freitas et al., 2012) to $89 \%$ (Czeder et al., 2012), lower than that observed in this study for BAF (Table 5). However, Fernandes et al. (2010) reported AAS values around $100 \%$ for baru almond, which is comparable to that found in the present study. Autoclaved BAF showed protein efficiency approximately $30 \%$ higher than that of in natura BAF. The improved protein quality of autoclaved BAF, estimated by NPR and PDCAAS, is a result of the protein digestibility improved by the heating process (autoclaving), which induces the inactivation of antinutrients and the desnaturation of proteins (Muzquiz et al., 2012). Czeder et al. (2012) investigated the protein quality of roasted baru almonds from the southeast area of Goiás State by NPR, and the authors found a value of 2.76, which is comparable to that of autoclaved BAF (Table 6). PDCAAS value of autoclaved BAF (81\%) was higher than those found in the literature for whole baru almond, from $65 \%$ to $73 \%$ (Czeder et al., 2012).

The overall results of the present study suggest greater advantages on the consumption of autoclaved BAF, when compared to baru almond intake, as source of good quality protein and bioactive compounds. Therefore, this co-product of the baru almond may be used as a raw material with nutritional and health benefits in the formulation of several products, as granola, breakfast cereals, cereal bars and cookies.

\section{Conclusion}

The flour of partially defatted baru almond is a source of good quality protein, calcium and bioactive compounds, and it is rich in dietary fiber, iron and zinc. Autoclaved BAF can be used for human consumption, as a source of complementary protein and bioactive compounds in healthy diets, and as raw-material for processed foods with nutritional advantages.

\section{Acknowledgements}

This work was supported by CNPq and CAPES (Brazil).

\section{References}

Abe, L. T., Lajolo, F. M., \& Genovese, M. I. (2010). Comparison of phenol content and antioxidant capacity of nuts. Ciência e Tecnologia de Alimentos, 30(Suppl. 1), 254-259. http://dx.doi.org/10.1590/ S0101-20612010000500038.

Alves, C. Q., David, J. M., David, J. P., Bahia, M. V., \& Aguiar, R. M. (2010). Métodos para determinação de atividade antioxidante in vitro em substratos orgânicos. Química Nova, 33(10), 2202-2210.

American Oil Chemist's Society - AOCS. (2009). Official methods and recommended pratices of the American Oil Chemist's Society. Champaign: AOCS.

Association of Official Analytical Chemists - AOAC. (2010). Official methods of analysis (19th ed.). Washington: AOAC.

Bento, A. P. N., Cominetti, C., Simões Filho, A., \& Naves, M. M. V. (2014). Baru almond improves lipid profile in mildly hypercholesterolemic subjects: a randomized, controlled, crossover study. Nutrition, Metabolism, and Cardiovascular Diseases, 24(12), 1330-1336. http:// dx.doi.org/10.1016/j.numecd.2014.07.002 PMid:25149894.

Blois, M. S. (1958). Antioxidant determination by the use of stable free radical.Nature, 181(4617), 1199-2000. http://dx.doi. org/10.1038/1811199a0.

Brand-Williams, W., Cuvelier, M. E., \& Berset, C. (1995). Use of a free radical method to evaluate antioxidant activity. $L W T$ - Food Science and Technology, 28(1), 25-30.

Czeder, L. P., Fernandes, D. C., Freitas, J. B., \& Naves, M. M. V. (2012). Baru almonds from different regions of the Brazilian Savanna: implications on physical and nutritional characteristics. Agricultural Science, 3(5), 745-754. http://dx.doi.org/10.4236/as.2012.35090. 
Fernandes, D. C., Freitas, J. B., Czeder, L. P., \& Naves, M. M. V. (2010). Nutritional composition and protein value of the baru (Dipteryx alata Vog.) almond from the Brazilian Savanna. Journal of the Science of Food and Agriculture, 90(10), 1650-1655. http://dx.doi.org/10.1002/ jsfa.3997. PMid:20564449

Food and Agriculture Organization of the United Nations - FAO. (1991). Protein quality evaluation. Rome: FAO.

Freitas, J. B., \& Naves, M. M. V. (2010). Composição química de nozes e sementes comestíveis e sua relação com a nutrição e saúde. Revista de Nutrição, 23(2), 269-279. http://dx.doi.org/10.1590/ S1415-52732010000200010.

Freitas, J. B., Fernandes, D. C., Czeder, L. P., Lima, J. C., Sousa, A. G. O., \& Naves, M. M. V. (2012). Edible seeds nuts grown in Brazil as sources of protein for human nutrition. Food and Nutrition Sciences, 3(6), 857-862. http://dx.doi.org/10.4236/fns.2012.36114.

Genovese, M. I., Pinto, M. S., Gonçalves, A. E. S. S., \& Lajolo, F. M. (2008). Bioactive compounds and antioxidant capacity of exotic fruits and commercial frozen pulps from Brazil. Food Science \& Technology International, 14(3), 207-214. http://dx.doi. org/10.1177/1082013208092151.

Guimarães, R. C. A., Favaro, S. P., Viana, A. C. A., Neto Braga, J. A., Neves, V. A., \& Honer, M. R. (2012). Study of the proteins in the defatted flour and protein concentrate of baru nuts (Dipteryx alata Vog.). Ciência e Tecnologia de Alimentos, 32(3), 464-470.

Higby, W. K. (1962). A simplified method for determination of some aspects of the carotenoid distribution in natura and carotene - fortified orange juice. Journal of Food Science, 27(1), 42-49. http:// dx.doi.org/10.1111/j.1365-2621.1962.tb00055.x.

Institute of Medicine. (2000). Dietary Reference Intakes: vitamin C, vitamin E, selenium and carotenoids. Washington: National Academy Press.

Institute of Medicine. (2014). Dietary Reference Intakes: recommended intakes for individuals. Retrieved from: http://www.iom.edu/ Activities/Nutrition/Summary DRIs/ /media/Files/Activity\%20 Files/Nutrition/DRIs/5_Summary\%20Table\%2Tables\%2014.pdf.

Merril, A. L., \& Watt, B. K. (1973). Energy value of foods: basis and derivation. Washington: United States Department of Agriculture.

Moore, S., \& Stein, W. H. (1951). Chromatography of amino acids on sulfonated polystyrene resins. The Journal of Biological Chemistry, 192(2), 663-681. PMid:14907661.

Muzquiz, M., Varela, A., Burbano, C., Cuadrado, C., Guillamón, E., \& Pedrosa, M. M. (2012). Bioactive compounds in legumes: pronutritive and antinutritive actions. Implications for nutrition and health. Phytochemistry Reviews, 11(2-3), 227-244. http://dx.doi. org/10.1007/s11101-012-9233-9.

Niki, E. (2014). Role of vitamin E as a lipid-soluble peroxyl radical scavenger: in vitro and in vivo evidence. Free Radical Biology \& Medicine, 66, 3-12. http://dx.doi.org/10.1016/j.freeradbiomed.2013.03.022. PMid:23557727

Pellet, P. L., \& Young, V. R. (1980). Nutritional evaluation of protein foods. Tokyo: The United Nations University.

Prosky, L., Asp, N. G., Schweizer, T. F., DeVries, J. W., \& Furda, I. (1988). Determination of insoluble, soluble, and total dietary fiber in foods and food products: interlaboratory study. Journal - Association of Official Analytical Chemists, 71(5), 1017-1023. PMid:2853153.

Raes, K., Knockaert, D., Struijs, K., \& Van Camp, J. V. (2014). Role of processing on bioaccessibility of minerals: Influence of localization of minerals and antinutritional factors in the plant. Trends in Food Science \& Technology, 37(1), 32-41. http://dx.doi.org/10.1016/j. tifs.2014.02.002.

Ramos, M. I. L., Umaki, M. C. S., Hiane, P. A., \& Ramos Filho, M. M. (2001). Efeito do cozimento convencional sobre os carotenóides pró-vitamínicos "A" da polpa de piqui (Caryocar brasiliense Camb.). Boletim do Centro de Pesquisa e Processamento de Alimentos, 19(1), 23-32.

Reeves, P. G., Nielsen, F. H., \& Fahey, G. C. J.Jr (1993). AIN-93 purified diets for laboratory rodents: final report of the American Institute of Nutrition ad hoc writing committee on the reformulation of the AIN-76A rodent diet. The Journal of Nutrition, 123(11), 1939-1951. PMid:8229312.

Roberfroid, M., Gibson, G. R., Hoyles, L., McCartney, A. L., Rastall, R., Rowland, I., Wolvers, D., Watzl, B., Szajewska, H., Stahl, B., Guarner, F., Respondek, F., Whelan, K., Coxam, V., Davicco, M. J., Léotoing, L., Wittrant, Y., Delzenne, N. M., Cani, P. D., Neyrinck, A. M., \& Meheust, A. (2010). Prebiotic effects: metabolic and health benefits. The British Journal of Nutrition, 104(Suppl 2), S1-S63.http://dx.doi. org/10.1017/S0007114510003363. PMid:20920376

Slavin, S., Petersen, G. E., \& Lindhal, P. C. (1975). Determination of heavy metals in meats by atomic absorption spectroscopy. Atomic Absorption Newsletter, 13(3), 57-59.

Sousa, A. G. O., Fernandes, D. C., Alves, A. M., Freitas, J. B., \& Naves, M. M. V. (2011). Nutritional quality and protein value of exotic almonds and nut from the Brazilian Savanna compared to peanut. Food Research International, 44(7), 2319-2325. http://dx.doi. org/10.1016/j.foodres.2011.02.013.

Stelmashook, E. V., Isaev, N. K., Genrikhs, E. E., Amelkina, G. A., Khaspekov, L. G., Skrebitsky, V. G., \& Illarioshkin, S. N. (2014). Role of zinc and copper ions in the pathogenetic mechanisms of Alzheimer's and Parkinson's diseases. Biochemistry, 79(5), 391-396. http://dx.doi.org/10.1134/S0006297914050022. PMid:24954589

Takemoto, E., Okada, I. A., Garbelotti, M. L., Tavares, M., \& Aued-Pimentel, S. (2001). Composição química da semente e do óleo de baru (Dipteyrx alata Vog.) nativo do município de Pirenópolis, Estado de Goiás. Revista do Instituto Adolfo Lutz, 60(2), 113-117.

Togashi, M., \& Sgarbieri, V. C. (1994). Proximate chemical characterization of the baru (Dipteryx alata Vog.) fruit. Ciência e Tecnologia de Alimentos, 14, 85-95.

Weaver, C. M., \& Kannan, S.(2002). Phytate and mineral bioavailability. In N. R. Reddy\&S. K. Sathe (Eds.), Food phytates (cap. 13, pp. 211-223). Florida: CRC.

World Health Organization - WHO. (2007). Protein and amino acid requirements in human nutrition. Geneva: WHO. 